\title{
Toi, c'est moi (1936) and Prends la route (1937): mobilising desire in the operetta films of Jacques Pills and André Tabet
}

\section{Phil Powrie}

To cite this article: Phil Powrie (2016): Toi, c'est moi (1936) and Prends la route (1937):

mobilising desire in the operetta films of Jacques Pills and André Tabet, Historical Journal of Film, Radio and Television, DOI: 10.1080/01439685.2016.1189157

To link to this article: http://dx.doi.org/10.1080/01439685.2016.1189157

曲 Published online: 07 Jun 2016.

Submit your article to this journal $₫$

Џll Article views: 4

Q View related articles $\sqsubset$

View Crossmark data ¿ 


\section{TOI, C'EST MOI (1936) AND PRENDS LA ROUTE (1937): MOBILISING DESIRE IN THE OPERETTA FILMS OF JACQUES PILLS AND ANDRÉ TABET}

\section{Phil Powrie}

Operetta films were one of the most popular film genres in France during the 1930 s through to the 1950s. Some films were film versions of stage shows, others were made specifically for cinema. Jacques Pills and André Tabet formed a successful male duo in the 1930s, and made two largely forgotten but successful operetta films. Toi, c'est moi/You are Me (René Guissart, 1936) was originally a stage operetta, while their follow-up Prends la route/On the Road (Jean Boyer, 1937) was written for the cinema. Both of the films involve travel, the first to the colonies (the Antilles); the second, which has as its focus the popular pastime of touring, travel around France. As is the case for other musical films, both films are utopian, the second in particular corresponding to the aspirations that led to the short-lived but politically influential Popular Front 1936-1938.

Discussion of music in the French cinema of the 1930s has tended to focus on the socalled realist singers with their one or two songs per film, and the musical films of René Clair, beginning with Sous les toits de Paris/Under the Roofs of Paris ${ }^{1}$ in 1930, quickly followed by À nous la liberté/[Give Us Freedom] (1931) and Le Million/[The Million] (1931). There has been little scholarly interest in a major popular genre from the 1930s to the 1950s in France, the operetta film. In this article, I will outline the two major manifestations of music in the French cinema of the 1930s, realist songs and operetta films, emphasising the latter. I will then focus on the operetta films of the male duo Jacques Pills (1906-1970) and Georges Tabet (1905-1984), who had two significant successes in the mid-1930s: Toi c'est moi/[You Are Me]

Correspondence to: Phil Powrie, School of English and Language, University of Surrey, Guildford, Surrey, GU27 7XH, UK. E-mail: p.powrie@surrey.ac.uk 
(René Guissart, December 1936) and Prends la route/[Take to the Road] (Jean Boyer and Louis Chavance, February 1937). What interests me in these two films is their relationship to a key historical moment in 1930s France: the coming to power of the first left-wing government, known as the Front Populaire (Popular Front). This lasted from May 1936 until the autumn of 1938, during which period the two films were released. I show how the musical numbers in the two films function to create the community and the values associated with the Popular Front.

\section{Realist chanson and operetta}

The 1930s and the coming of sound changed the performance landscape in France as it did in Hollywood. Songs in films became widespread, as singers hitherto confined to the stage, radio or records were integrated in films in a variety of ways and across different genres. As Giusy Pisano explains, song in general permeated French society through a wide variety of formats, whether radio, records, print media such as songsheets or the popular press, and of course cinema. ${ }^{2}$ Pisano has established that songs occur in some 740 French films during the 1930s. ${ }^{3}$ There was considerable exchange between these different media; not only were preexisting songs used in films, but songs created for films were then broadcast using other media.

Several types of musical performance on screen became established by the end of the decade. First, films in which individual singers, generally from the music-hall tradition, perform no more than two or three songs. These have had considerable scholarly attention, for example, in Kelley Conway's important book on the women realist singers, such as Damia, Florelle, Fréhel and Édith Piaf. ${ }^{4}$ These films do not in my view constitute a musical film genre, not least because the songs are incidental to the narrative. Seeing a well-known singer perform on screen would clearly have been attractive to audiences, and would, as Conway points out, ${ }^{5}$ been a way to sell a film, but it was not the film's focus. Other films in this period had rather more focus on songs. This was the case with films based on a revue show, such as Paris-Béguin (Augusto Genina, 1931), with Jean Gabin, or two films starring Josephine Baker, who had made her name in the 1920s with the Revue Nègre: Zouzou (Marc Allégret, 1934), which also starred Gabin, and Princesse Tam-Tam (Edmond T. Greville, 1935), which starred Albert Préjean, who is the main protagonist of Clair's Sous les toits de Paris. ${ }^{6}$ A third type of musical film, this one with many more musical numbers, is the big band film, these typically being backstage musicals whose narrative involves the band working towards putting on a show, and in which there are usually six songs. Although the heyday of the big band musical was during the 1940s and 1950s, it emerged in the 1930s, the major exponent being the bandleader Ray Ventura, with four popular pre-war films. His first film was Tout va très bien Madame la Marquise/[Everything is Alright, Madame la Marquise] (Henry Wulschleger, 1936); the title is one of the band's most popular songs, on which the film was based. This was followed by Aventure à Paris/Adventure in Paris (Marc Allégret, 1936), Feux de joie/[Bonfires] (Jacques Houssin, 1938), and then Tourbillon de Paris/Whirlwind of Paris (Henri Diamant-Berger, 
1939), before the band left for South America for fear of persecution, as Ventura was Jewish. 7

The operetta film is different, not least because it has many more musical numbers than the half-dozen found in the big band films. These films came on the back of a well-established nineteenth-century tradition. Operetta emerged in France in the mid-nineteenth century as a light and usually saucy variant of the increasingly serious and misnamed opéra comique. Jacques Offenbach is the best example of the operetta in France, with Johann Strauss II emerging in Austria in the 1870s (Die Fledermaus was in 1874), and Gilbert and Sullivan in the UK in the same period. The operetta as a stage form saw something of a lull with the turn of the century, but returned to the Paris stages in 1918, with a new generation of composers incorporating jazz rhythms from the USA, amongst them Moïse Simons, the composer for Toi c'est moi. ${ }^{8}$ A decade later, with the coming of sound, operettas were made into films, many of these being composed specifically for cinema.

A particularly interesting feature of this period is the short-lived multi-language vehicle (MLV), where a film was made in two or more different language versions (typically French and German). ${ }^{9}$ This was not confined to musical films, of course; there were no less than 300 MLVs (both shorts and features) produced by Paramount in its Paris studios at Joinville 1929-1933 (which accounts for the production credits to the USA for some of the films in Table 1). ${ }^{10}$ As Barnier points out, however, operetta films did particularly well in this environment; he puts this down to the gaiety of the films and the quality of the songs and singers. ${ }^{11} \mathrm{He}$ points out that one of the songs from one of the first MLV operettas, Le Chemin du paradis/The Road to Paradise (William Thiele, 1930), 'Avoir un bon copain' (Having a Good Friend), remained sufficiently popular over the years that Alain Resnais used it in his musical film On connaît la chanson/Same Old Song (1997) and that it was sung by a contemporary singer, Bénabar, as part of the soundtrack for Incognito (Éric Lavaine, 2009), a story about an up-and-coming singer. ${ }^{12}$

As can be seen in Table 1, MLVs for the operetta films are concentrated in the early 1930s. As is to be expected, many of the French personnel can be found repeating their successes: the directors, Max de Vaucorbeil has three operettas, Roger Le Bon and Louis Mercanton have two operettas each, René Guissart two before directing Toi c'est moi; while Jean Boyer wrote three librettos before turning his hand to writing the libretto and directing Prends la route. And we can note that Raoul Moretti appears as the composer of no fewer than five of the listed films, and Walter Heymann four times.

The success of this new film genre was partly due to the rise of the Hollywood operetta, with the pairing of Maurice Chevalier and Jeannette MacDonald, ${ }^{13}$ followed by Jeannette MacDonald and Nelson Eddy later in the decade. ${ }^{14}$ The operetta film remained popular in France into the late 1950s with the 'three tenors': Tino Rossi, Georges Guétary and Luis Mariano. Mariano in particular garnered cinema audiences of several million for his big-budget spectaculars, with 5.7 million for Andalousie/Andalusia (Robert Vernay, 1951), the top-selling French film of its year. ${ }^{15}$ Operetta, therefore, was a long-lived genre in France, reaching its apogee in the films of the 1930-1950 period. 
TABLE 1 Selection of operetta films in the 1930s

\begin{tabular}{|c|c|c|c|c|c|c|}
\hline Year & $\begin{array}{l}\text { Original } \\
\text { operetta }\end{array}$ & Title & Director(s) & Country & Libretto & Music \\
\hline 1930 & & $\begin{array}{l}\text { Le Chemin du } \\
\text { paradis }\end{array}$ & $\begin{array}{l}\text { Thiele, } \\
\text { Vaucorbeil }\end{array}$ & $\mathrm{Fr} / \mathrm{Ger}$ & Frank, Schulz & Heymann \\
\hline 1930 & 1928 & $\begin{array}{l}\text { L'Opéra de quat' } \\
\text { sous }\end{array}$ & Pabst & $\begin{array}{l}\text { Ger/ } \\
\text { USA/Fr }\end{array}$ & Brecht & Weill \\
\hline 1931 & & $\begin{array}{l}\text { Le Congrès } \\
\text { s'amuse }\end{array}$ & $\begin{array}{l}\text { Charell, } \\
\text { Boyer }\end{array}$ & $\mathrm{Fr} / \mathrm{Ger}$ & Falk, Liebmann & Heymann \\
\hline 1931 & & $\begin{array}{l}\text { Princesse, à vos } \\
\text { ordres! }\end{array}$ & $\begin{array}{l}\text { Schwarz, } \\
\text { Vaucorbeil }\end{array}$ & $\mathrm{Fr} / \mathrm{Ger}$ & $\begin{array}{l}\text { Boyer, Frank, } \\
\text { Liebmann, Wilder }\end{array}$ & Heymann \\
\hline 1931 & 1925 & Pas sur la bouche & $\begin{array}{l}\text { Evreinoff, } \\
\text { Rimsky }\end{array}$ & $\mathrm{Fr}$ & Barde & Yvain \\
\hline 1931 & & $\begin{array}{l}\text { Son altesse } \\
\text { l'amour }\end{array}$ & $\begin{array}{l}\text { Péguy, } \\
\text { Schmidt }\end{array}$ & $\mathrm{Fr} / \mathrm{Ger}$ & $\begin{array}{l}\text { Bernauer, Decoin, } \\
\text { Lantz, Pujol }\end{array}$ & $\begin{array}{l}\text { Jurmann, } \\
\text { Kapper }\end{array}$ \\
\hline 1931 & & Marions-nous & Mercanton & $\mathrm{Fr}$ & Saint-Granier & $\begin{array}{l}\text { Whiting, Borel- } \\
\text { Clerc }\end{array}$ \\
\hline 1931 & & $\begin{array}{l}\text { Un caprice de la } \\
\text { Pompadour }\end{array}$ & $\begin{array}{l}\text { Hamman, } \\
\text { Wolff }\end{array}$ & $\mathrm{Fr}$ & Falk, Rameau, Wolff & $\begin{array}{l}\text { Kunnicke, Stolz, } \\
\text { Strasser }\end{array}$ \\
\hline 1931 & & $\begin{array}{l}\text { Le Costaud des } \\
\text { P.T.T. }\end{array}$ & Bertin, Maté & $\mathrm{F}$ & Roda-Roda & $\begin{array}{l}\text { Chagnon, } \\
\text { Moretti }\end{array}$ \\
\hline 1931 & & $\begin{array}{l}\text { Le Capitaine } \\
\text { Craddock }\end{array}$ & $\begin{array}{l}\text { Schwarz, } \\
\text { Vaucorbeil }\end{array}$ & $\mathrm{Fr} / \mathrm{Ger}$ & Lee, Müller, Schulz & Heymann \\
\hline 1932 & & Ronny & $\begin{array}{l}\text { Le Bon, } \\
\text { Schünzel }\end{array}$ & $\mathrm{Fr} / \mathrm{Ger}$ & $\begin{array}{l}\text { Pressburger, } \\
\text { Schünzel }\end{array}$ & Grothe \\
\hline 1932 & & II est charmant & Mercanton & $\mathrm{Fr} / \mathrm{Sw}$ & Willemetz & Moretti, Cadou \\
\hline 1932 & & $\begin{array}{l}\text { La Fille et le } \\
\text { garçon }\end{array}$ & $\begin{array}{l}\text { Le Bon, } \\
\text { Thiele }\end{array}$ & $\mathrm{Fr} / \mathrm{Ger}$ & Ploquin, Schulz & Gilbert \\
\hline 1933 & 1932 & Au pays du soleil & Péguy & $\mathrm{Fr}$ & Alibert, Sarvil & Scotto \\
\hline 1933 & 1932 & $\begin{array}{l}\text { Un soir de } \\
\text { réveillon }\end{array}$ & Anton & $\mathrm{Fr}$ & Boyer, Schiller & Moretti \\
\hline 1934 & 1921 & Dédé & Guissart & $\mathrm{Fr}$ & $\begin{array}{l}\text { Bousquet, Boyer, } \\
\text { Willemetz }\end{array}$ & Christiné \\
\hline 1935 & 1905 & La Veuve joyeuse & Lubitsch & Fr/USA & Achard, Vajda & Lehar \\
\hline 1935 & 1927 & $\begin{array}{l}\text { Le Comte } \\
\text { Obligado }\end{array}$ & Mathot & $\mathrm{Fr}$ & Pujol & Moretti \\
\hline 1935 & 1934 & $\begin{array}{l}\text { Les Sœurs } \\
\text { Hortensias }\end{array}$ & Guissart & $\mathrm{Fr}$ & $\begin{array}{l}\text { Barde, Duvernois, } \\
\text { Falk }\end{array}$ & Moretti \\
\hline 1936 & 1934 & Toi c'est moi & Guissart & $\mathrm{Fr}$ & Duvernois, Willemetz & Simons \\
\hline 1937 & & Prends la route & $\begin{array}{l}\text { Boyer, } \\
\text { Chavance }\end{array}$ & $\mathrm{Fr}$ & Boyer & Van Parys \\
\hline
\end{tabular}




\section{Pills and Tabet}

Pills and Tabet formed their duo in 1930. As was normal for many film actors in the period, they became popular in the first instance as singers, having made their name in the early 1930s singing American jazz songs alongside music hall stars in various revues: Mistinguett and Jean Gabin in 'Paris qui brille' (Paris Glitters) at the Moulin Rouge (1931), Marie Dubas in 'Paris-Sex Appeal' at the Casino de Paris (1932), and Josephine Baker in 'La Joie de Paris' (The Joy of Paris) the same year.

Amongst their best-known songs are 'Nous serons toujours heureux' (We Will Always Be Happy), 'Fumée aux yeux' (Smoke in Your Eyes), 'Jeunes mariés' (Newly-Weds) and 'Couchés dans le foin' (Lying in the Hay), a song that won the Grand Prix du Disque in 1932. Their stage trademark was Tabet at the piano (he was a former jazz-band leader as well as a composer), and the elegantly dressed Pills standing either at the microphone or leaning on the piano. This staging was copied from American singers such as Layton and Johnstone or the Revellers, according to Louis-Jean Calvet, who gives Pills and Tabet the label 'élégance, dynamisme et jazz', ${ }^{16}$ and points out that they paved the way for the singing star Charles Trenet, who based his duo Charles et Johnny with Johnny Hess in 1933 on Pills and Tabet. ${ }^{17}$ Pills and Tabet were successful in the USA, where according to the press they were nicknamed 'Pills and Tablets', as is recounted in a popular film magazine when Toi c'est moi was released. ${ }^{18}$ They parted company in 1939 when Pills began a solo career, marrying the singer Lucienne Boyer the same year. The 'Pills and Tablets' moniker stuck even after they had parted, as a journalist doing a piece on Pills in 1940 comments: '[Pills] connaît un "tas" d'anecdotes [...] puisque même son nom en est une, Pills veut dire pilules en anglais, comme chacun sait. Si bien que les Américains ne manquèrent point de citer "Pills and Tablets", 19

Boyer and Pills shared the same impresario, Bruno Coquatrix, whose songs they sang on stage and on film. In 1942, Pills starred in Pension Jonas (Pierre Caron), in which he sang two songs by Coquatrix, again singing a couple of songs in a 1945 film, Seul dans la nuit/Alone in the Night (Christian Stengel), including the title song. He also had a starring role in Une femme par jour/[A Woman per Day] (1949), a film directed by Jean Boyer (who had directed Prends la route), and produced by Ray Ventura, the big band conductor mentioned above.

He had an international singing career after the war, touring the USA in the early 1950s, with Gilbert Bécaud as his piano accompanist. He met Édith Piaf during this tour, and they married in 1952. Pills and Bécaud wrote a song for Piaf, 'Je t'ai dans la peau' (You're Under My Skin), ${ }^{20}$ which was included in the musical revue film in which Pills had the leading role, Boum sur Paris/[Boum over Paris] (Maurice de Canonge, 1953), with appearances by Piaf and Trenet amongst others. In the following years, Piaf and Pills performed together (the Moulin Rouge in 1954, the Olympia in 1955), but divorced in 1956. In 1959, he was the Monaco contestant in the Eurovision Song Contest, where he finished last. ${ }^{21}$ Jacqueline Pills, his daughter by his first marriage to Lucienne Boyer, whom he had divorced in 1951, managed to win the same contest the following year in 1960. The success of the yé-yé singers in the early 1960s, such as Johnny Hallyday, put an end to his 
career, and in the last few years before his death in 1970, he gave lessons in music-hall in Bruno Coquatrix's Olympia. ${ }^{22}$

Tabet's career after he and Pills parted was more firmly in the cinema. After dabbling in composition, radio and theatre, he had some bit parts in a range of films in the early 1950s. These included a Tino Rossi musical, Au pays du soleil/In the Country of the Sun (Maurice de Canonge, 1951), and Mandat d'amener/The Warrant (Pierre-Louis, 1953), scripted by his brother, André Tabet. He joined his brother as a scriptwriter subsequently, scripting some 26 films between 1954 and 1974, including some of French cinema's most popular successes: Une ravissante idiote/Agent 38-24-36 (Edouard Molinaro, 1964), starring Brigitte Bardot; Le Corniaud/The Sucker (Gérard Oury, 1965); La Grande vadrouille/The Big Runaround (Gérard Oury, 1966); and Point de chute/Falling Point (Robert Hossein, 1970), starring Johnny Hallyday. ${ }^{23}$

\section{The films}

I have chosen to focus on Prends la route and Toi, c'est moi, partly because of the way that they play out social and political tendencies at the time of the Popular Front, but also partly because they focus on a male duo, unlike the standard operetta's focus on the romantic couple. In these films, Jacques Pills plays an upper-class lothario, who ends up getting his girl, while Georges Tabet plays a middle- or lower-class character who is generally the butt of jokes, in a standard comic duo pairing.

Toi, c'est moi, their first film, was adapted from a very successful stage operetta. It was performed 265 times from 19 September 1934 to 10 June 1935 at the Théâtre des Bouffes Parisiens, and reprised for a further 94 performances at the Apollo from 27 December 1941 to 30 March 1942. ${ }^{24}$ It also played in London and Budapest; it was so successful that it was reprised on the Paris stage during the winter of 2005-2006. The plot plays on mistaken identities. Bob (Jacques Pills) parties all the time while pretending to work, thanks to the financial support of a wealthy widowed aunt (Pauline Carton). When she discovers his fecklessness, she sends him to her plantation in the Antilles to learn about the world of work. ${ }^{25}$ He is accompanied by his best friend, Pat (Georges Tabet), whom he persuades to take his place, hence the film's title, 'you are me'. However, Bob falls for the wild (white) daughter of the plantation manager; but her father wants her to marry Pat, whom he believes to be the nephew who will inherit. Pat, meanwhile, is the object of a local (black) woman's attentions, in a typical upstairs-downstairs configuration. Much of the comedy is focused on the two friends' attempts to recover their real identities; a running slapstick gag has Pat dowsed with a bucket of water every time he claims to be Pat rather than the rich nephew. The aunt decides to visit the island in a surprise visit to check up on her nephew. The climate causes all of the characters, including the aunt, to fall in love, so that much of the second half of the film is devoted to the courting of a variety of couples. Pills and Tabet reprise their stage roles, as does Pauline Carton in the role of the aunt. The role of the daughter of the plantation manager had been played by Simone Simon in the play. She had gone to Hollywood in 1935 after the first run of the play at the 
Bouffes Parisiens where she worked, and was replaced by the less-temperamental Claude May, who also plays a lead role in Pills and Tabet's second film.

Audiences and critics appreciated the duo's polished musical performances. One critic writes in extraordinarily eulogistic tones as follows:

Avec une aisance charmante, leurs voix flexibles cheminent parallèlement le long de la chanson, s'écartent, se rejoignent, se séparent, et se croisent en des méandres imprévus et ravissants. Si l'un se tait un instant, on croit que c'est l'autre qui a la plus jolie voix. Mais si celui-ci s'interrompt à son tour, on donne sa langue au chat ... [...] Les deux voix, libres, paraissent pourtant soudées l'une à l'autre par un impérieux sentiment musical. Que le mouvement s'accélère ou s'alanguisse en des inflexions caressantes ou ironiques, jamais l'ensemble ne souffre du plus infime décalage. C'est cette perfection qui leur donne un rythme à la fois si précis et si souple et leur permet d'enrouler leurs arabesques vocales avec tant d'infaillible sûreté. La liberté, la fantaisie, la pureté de leur style, fruit d'un long travail de mise au point, ravissent profanes et connaisseurs. Chacune de leur interprétation, chacun de leur disque est un petit chef-d'œuvre de perfection et d'humour. ${ }^{26}$

Part of the film's freshness, according to critics, was its clever use of music by the composer Moïse Simons. Its nine musical numbers mix forms that had been around for some time, such as the one-step, the waltz and the fox-trot, with new LatinAmerican forms such as the rumba, the conga and the samba, congruent with the colonial setting.

Prends la route, which was released two months later, is based entirely in France. It has more songs, a dozen, and was built on the previous film's success, with Claude May again in a leading lady role alongside Pills and Tabet. Unlike Toi c'est moi, however, this operetta was written specifically for the screen by the director, Jean Boyer, and was filmed almost entirely in exteriors. This was partly because, as the title suggests, it was a film about the new phenomenon of touring, available to all classes whether on bicycles, motorbikes or cars. Bachelor Jacques (Jacques Pills) tries to shake off his mistress as he travels back to the family home where he is to be married off; his mistress pursues him with her wealthy lover, who is a Touring Club fanatic. Jacques meets Simone (Claude May) on the road; she and her chaperone have run out of petrol. Simone and Jacques elope, little knowing that she is the bride intended by his father. Tabet plays an annoying car insurance salesman, Potopoto, who tags along on his motorbike (hence the moniker, which represents the putt-putt of the motorbike's engine). The running gag in this film is that Potopoto drives dangerously on purpose to persuade potential customers to take out his insurance policy; they, naturally, are incensed by his antics, and refuse.

While Georges Van Parys's compositions are musically not so inventive as Moïse Simons's music for Toi c'est moi, Prends la route was, like the previous film, applauded for its freshness, by which was meant the devil-may-care attitude of the younger generation. In the regular readers' column of the popular film magazine Pour Vous, a reader wrote that the film 'commence par des chansons: la chanson de la jeunesse, des vacances, de la joie de vivre. C'est un film optimiste qu'il faut voir pour se ragaillardir' ${ }^{27}$; and a critic wrote in similar terms that 'cette fantaisie 
musicale est d'une fraîcheur, d'un entrain, d'une jeunesse irrésistibles', pointing out: 'Ce qui ne gâte rien, Prends la route se déroule presque exclusivement en extérieurs'. 28

The title song of the film is a fox-trot, which urges the French to take to the road. The French Touring Club had been established by cycling enthusiasts in 1890 , and had, along with the advent of camping, become a popular although not necessarily populist leisure activity. In the summer of 1936, following the creation of the Popular Front government, the Matignon Agreements gave French workers a range of benefits, amongst which were the 40-hour working week, and, for the first time, paid holidays. There was a mass exodus to the beaches and the countryside that summer. For many, it was the first holiday outside a city, literally constituting a breath of fresh air after the difficult 1920s with their postwar gloom followed by the financial crash of 1929. This is reflected in the song:

Quand des mois entiers on a respiré l'air de la ville

On se sent fragile et l'on ne tient plus sur ses pieds

On souffre du cour, on perd l'appétit, on est fébrile

Et comme on a peur, on va consulter son docteur

Prenez d'huile de ricin vous ordonne le médecin

Il f'rait mieux c'est certain d'vous dire s'il était plus malin

Prends la route mon p'tit gars, prends la route et n't'en fait pas

Tu guériras

Prends la route de ton choix

Prends la route et va tout droit

Elle est à toi

L'air de Paris te donne le tain gris

Mais le grand air te le rendra plus clair

Plus de goutte pour la toux

Prends la route elle guérit tout

Prends la route et met les bouts! ${ }^{29}$

Moreover, at the end of this number, which conveys the new freedom felt by ordinary people, we get a taste of the upward mobility that holidays and possible modes of transport have brought. We see a couple walking in the sun, when a tandem overtakes them. The wife asks her husband: 'Dis, chéri, ça coûte cher un tandem? A motorbike overtakes the tandem; the wife says: "Dis, chéri, ça coûte cher une moto?" A car overtakes the motorbike; the wife says: Dis, chéri, ça coûte cher une petite voiture?' The punchline is delivered when we see the grumpy aunt and her niece stranded in their car because they have run out of petrol, with the aunt saying, 'ça ne coûte peut-être pas très cher, mais ça ne marche pas!' ${ }^{30}$ As Philippe Frémeaux points out in his introduction to a CD compilation of songs released at the time of the Popular Front, there may not be an obvious connection between the politics of the period and most of its songs, but the Front's victory 'annonce l'entrée de la France dans le capitalisme moderne: la victoire électorale du Front traduit le fait que le salariat est devenu majoritaire dans la société', ${ }^{31}$ and that what the Popular Front brought was leisure time: 'Le vrai rapprochement entre le Front populaire et la chanson s'est fait partout où le temps arraché au travail, au patron, dans la grève ou grâce aux cong'pay', a permis aux amoureux de danser, rêver, 
s'aimer le temps d'une chanson. ${ }^{32}$ As we shall see, this pivotal moment between the old and the new is reflected in the films, particularly Toi c'est moi, although less so in Prends la route, in values that are organised along generational lines.

There is another good reason for choosing to concentrate on Prends la route. It is eminently watchable, and considerably more so than many of the minor films from the period. This is a point made by the historian Éric Remy in the same website as Frémeaux. What he admires, he writes, is:

Le gigantesque Touring Club Art Déco avec ses hôtesses en blouses de satin [...], les Bugatti, les knickerbockers, les incroyables lunettes des motocyclistes (sans casques!), la poule de luxe jouée par Colette Darfeuil, vedette complètement oubliée, les seconds rôles (Alerme, vieille ganache, Milly Mathis, commère marseillaise) et puis cette campagne française ensoleillée aux routes bordées de haies de peupliers et d'accortes paysannes qui sortent de chez le coiffeur. Ajoutons que Pills et Tabet sont meilleurs acteurs qu'on ne pourrait le croire, que la jeune première est plutôt moins mièvre que la moyenne du temps et qu'un orchestre assez swing enlève une partition excellente signée George van Parys. Bref [...] c'est l'une des très rares comédies musicales françaises qui ait résisté au passage des ans. ${ }^{33}$

\section{New values}

Both films depend on geographical displacement where the characters are tourists for whom travel means freedom to express their desires. This is most obvious in Toi c'est moi, where the duo go to the Antilles. The location in the hot and steamy tropics, and the associated music, stimulate the sexual desire of the characters, who all pair up and engage in what Barbara Creed calls the musical's 'mating game'. ${ }^{34}$ This is a frequent theme in the dialogue, when the plantation manager apologises for his daughter's wild ways; Jacques responds that it is due to the climate. Later, local musicians play 'jungle drums' (see Figure 1). This appears to prompt a series of passionate declarations by the main characters, who one by one declare their undying love for each other. The younger characters do this in more standard romantic style, while comedy is generated by the older characters who declare their love in farcically excessive style. So, for example, the climate again figures as the reason for sexual desire in a saucy dialogue between Adolphe, the Governor General of the island, and Honorine, the wealthy aunt, who misinterprets the meaning of 'tam-tam', clearly understanding it to mean sexual intercourse:

(Adolphe) - Vous avez les yeux profonds.

(Honorine) - J'ai la fièvre.

(Adolphe) - C'est le climat.

(Honorine) - Allons faire un tour ... cette atmosphère!

(Adolphe) - Vous aimez le tam-tam?

(Honorine) - Je ne sais pas, il y a si longtemps que je suis veuve.

(Adolphe) - Le tam-tam, c'est une sorte de bal nègre, je vais vous montrez ça.

(Honorine) - Mais, vous me jurez d'être sage? Gamin ... ${ }^{35}$ 


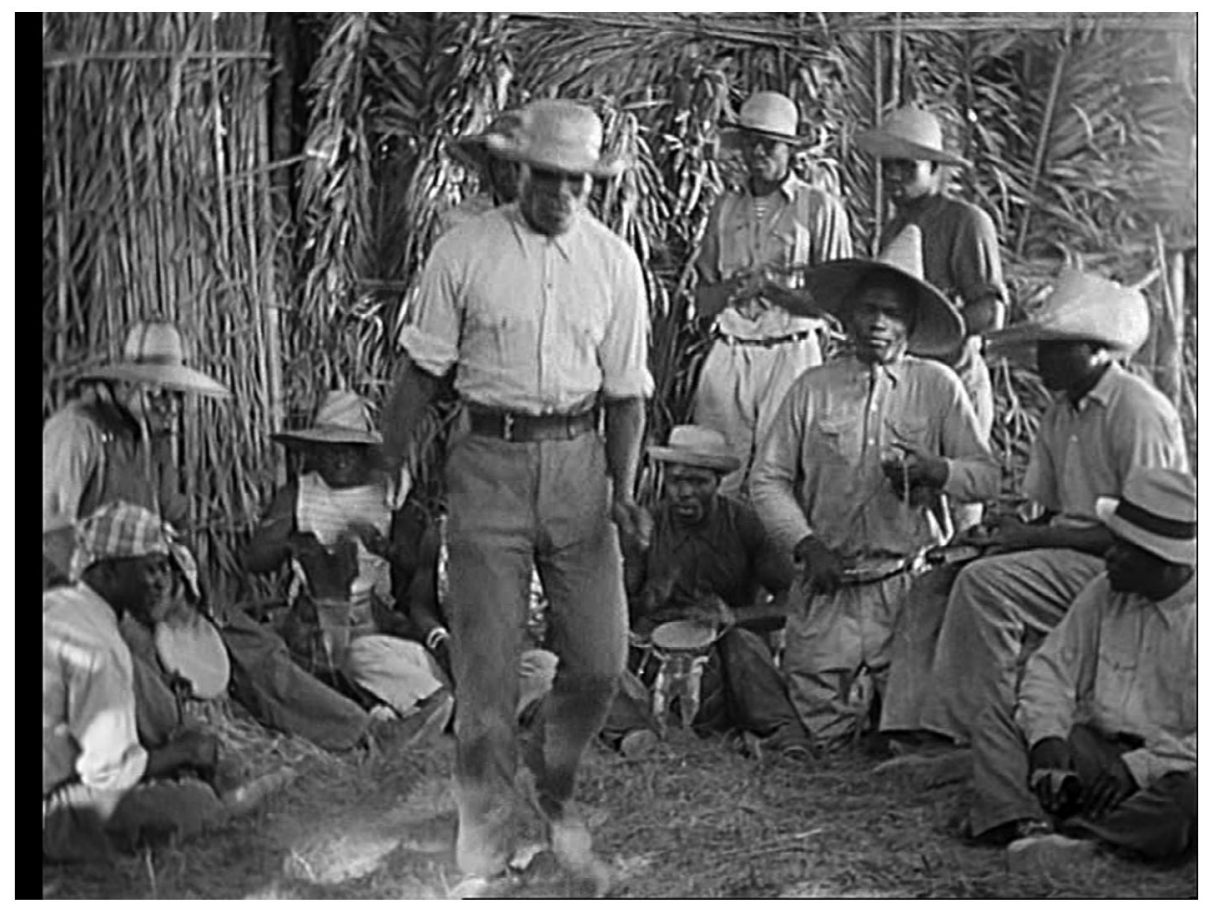

Figure 1. 'Jungle drums' in Toi c'est moi (courtesy René Chateau Vidéo).

Unbridled desire leads Honorine to respond to the advances of Pedro, the plantation manager, not long afterwards, in one of the 1930s' most memorable songs, 'Sous les paletuviers' (Under the Mangrove Trees; lyrics by Albert Willemetz), covered by many singers in the decades to follow. Its rapid-fire delivery, its comic rhymes and puns are part of the song's pleasure. But the rapid delivery also emphasises the rush of mounting sexual desire; and the stretching, disintegration and recomposing of words - particularly those in the refrain focusing on the key word 'paletuvier' - underlines the disintegration of propriety. Bodies are shot through with desire, which bubbles through the repeated syllables unanchored from their original words, as if the characters, powerfully moved by lust, can do no more than stammer incoherently:

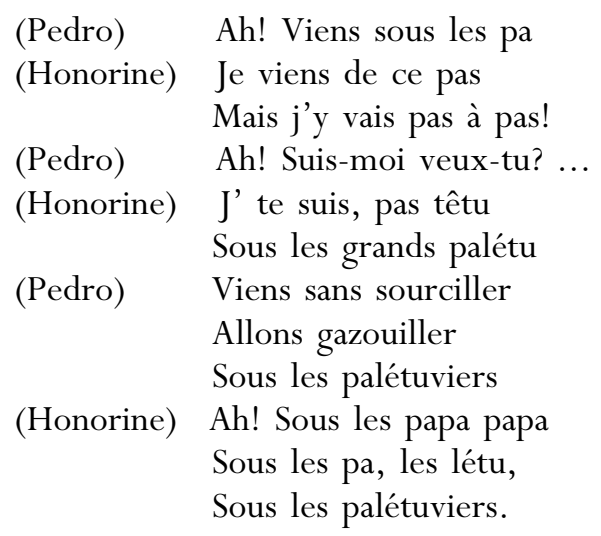


(Pedro) Ah! Je te veux sous les pa

Je te veux sous les lé,

Les palétuviers roses

(Both) Aimons-nous sous les palé

Prends-moi sous les létu

Aimons-nous sous l'évier! ${ }^{36}$

Sexual desire is rather differently presented by the younger characters, as befits a film that is more interested in modern times than in the more traditional type of vaudeville song represented by 'Sous les paletuviers', even if the lyrics are unusually inventive. It is telling that in Toi c'est moi, Jacques and Maricousa talk about their love of American films, and decide to act out what happens in them, kissing passionately:

(Jacques) - Est-ce qu'il y a beaucoup de distractions ici?

(Maricousa) - Pas énormément ... le cinéma une fois par mois.

(Jacques) - Vous aimez le cinéma?

(Maricousa) - Les films américains surtout ... Oh! Si on jouait aux films américains! Vous savez?

(Jacques) - J'apprendrai!

(Maricousa) - C'est simple. Je mettrai mes lèvres sur vos lèvres.

(Jacques) - Mais c'est pas une mauvaise idée! Essayons ... on verra bien ce que ça donnera! $!^{37}$

'What happens' is that Maricousa leaps up, to the consternation of Jacques, and starts singing what will become a standard romantic duet. Less standard is the fact that they later swim naked (Claude May's breasts are clearly - and unusually for the period - visible at one point), their clothes are stolen, and they emerge from the seashore in a Botticelli parody clothed only in seaweed, like Adam and Eve. The Governor of the island tells them without any irony intended: 'Vous êtes très bien comme ça' (see Figure 2). ${ }^{38}$ This is a far cry from the sophisticated verbal duet of 'Sous les paletuviers', but the impetus is the same. It is, as the characters keep on saying, the fault of the climate; and we could say that it is not just the climate of the Antilles, but the social and political climate of the Popular Front with its new-found freedoms focusing on leisure (paid holidays and the 40-hour working week). While these were not sexual freedoms, ${ }^{39}$ nonetheless, the emphasis on the erotic and the sexual in Toi c'est moi suggests freedom of expression, as well as by its very nature a certain kind of mobility.

Geographical displacement is also key to Prends la route, as is the excitement of the new; the novelisation of the film talks of the crowd of customers in the Touring Club offices being 'possédée d'une fièvre joyeuse'. ${ }^{40}$ In both films, characters come together, but whereas in Toi c'est moi, the emphasis is on sexual congress, in Prends la route it is more simply congress in the form of community. The film has the format of what came much later to be called the road movie, but which is a well-known literary form, the picaresque novel: as in Toi c'est moi, the characters meet other people and form new relationships as they travel. The narratives therefore bring characters together in new formations. There is also a significant shift from the first film to the second. In Toi c'est moi, there is still the stereotypical 


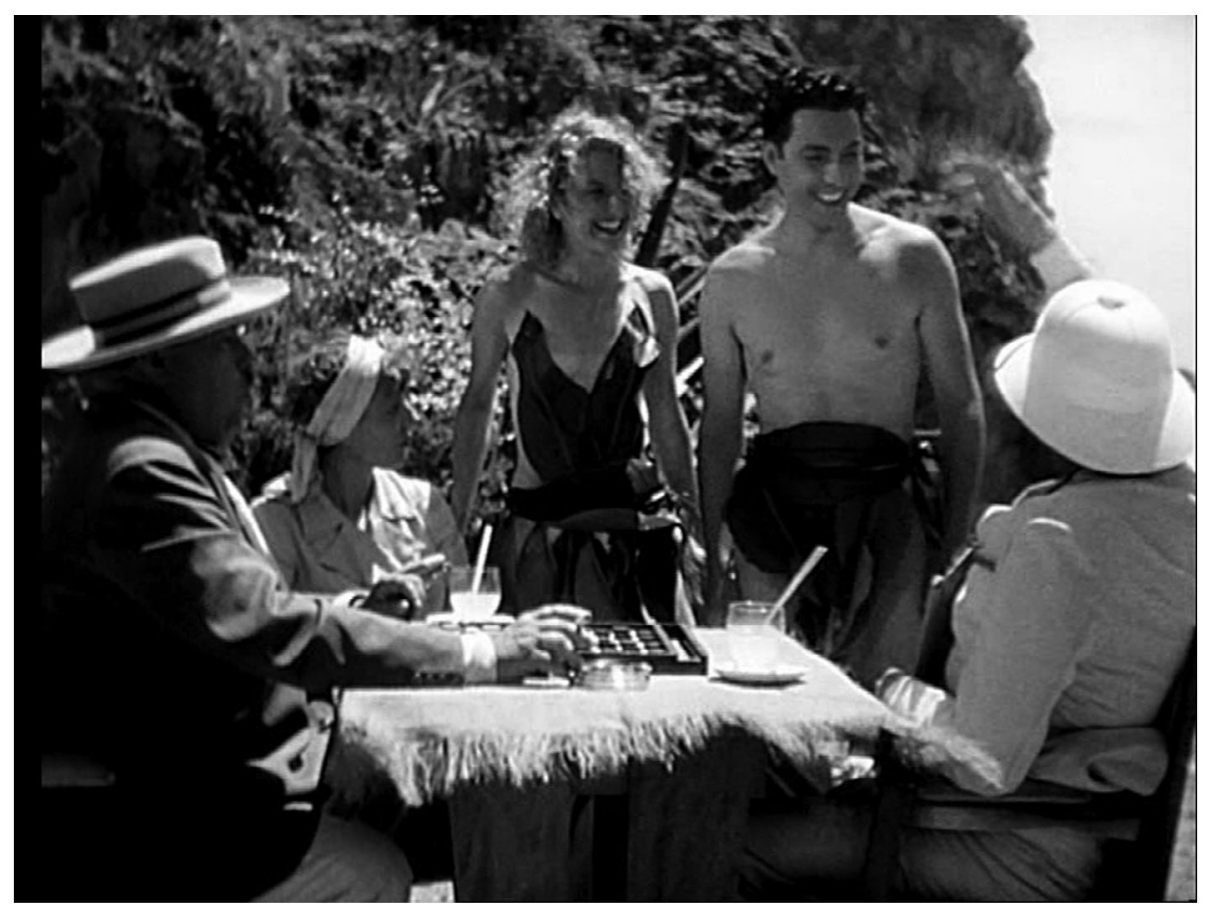

Figure 2. 'You look fine like that', in Toi c'est moi (courtesy René Chateau Vidéo).

upstairs-downstairs structure familiar in French theatre since the seventeenth century. In Prends la route, however, the very nature of touring brings the classes together in novel ways. The road is a great leveller, and that has made this film an even more obvious illustration first of structures of feeling at the time of the Popular Front, and second of popular recognition of the very real gains for working people in 1936. As Pierre Billard says, echoing Frémaux whom I quoted above, the film is 'considéré comme la meilleure illustration de la conquête des congés payés par le Front populaire'. 41

The staging of the musical numbers is important in suggesting this effect of community, as one might expect from film musicals more generally. ${ }^{42}$ In the films, the singers are often shown to be singing to an audience, to characters who gather round them to listen in rapt attention. This is the case, for example, for the two title songs of the films. In Toi c'est moi, Pills and Tabet sing to a group of young women with whom they have been partying (see Figure 3). In Prends la route, they sing to the customers in the Touring Club. Moreover, in Prends la route, the community is mobilised. Pills and Tabet gather the Touring Club customers, high and low alike, around themselves as they sing, and then lead them around the room as they sing, this image being superimposed at the end of the song by a further element of mobility, cars hurtling on the road away from the city (see Figure 4). In 'À mon âge' (At my Age), again from Prends la route, Jacques sings to his male friends; photographs and sculptures in his room are mobilised by the song in an imaginary community, which brings together Jacques's girlfriends, his father, and even a bust of Napoleon, who one by one join in the chorus. Jacques introduces 


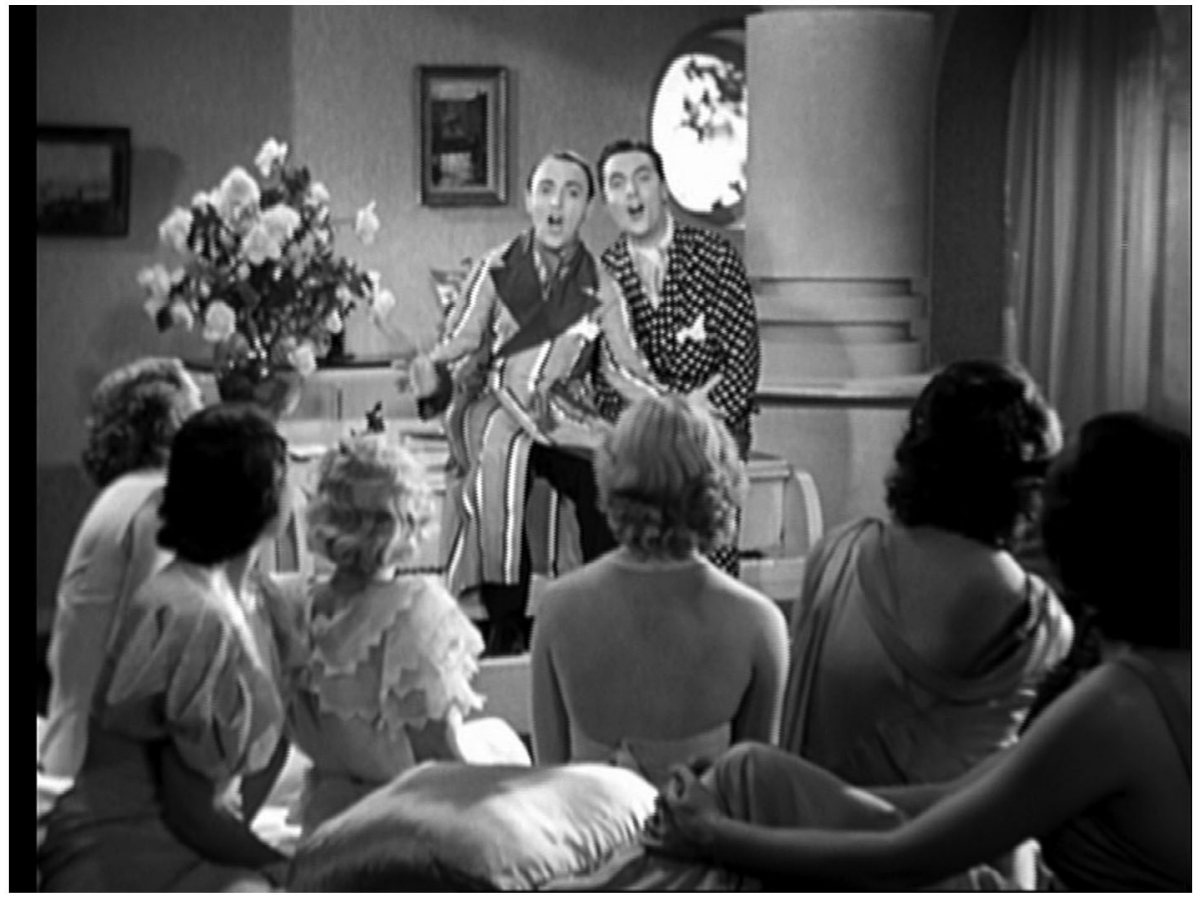

Figure 3. The audience in Toi c'est moi (courtesy René Chateau Vidéo).

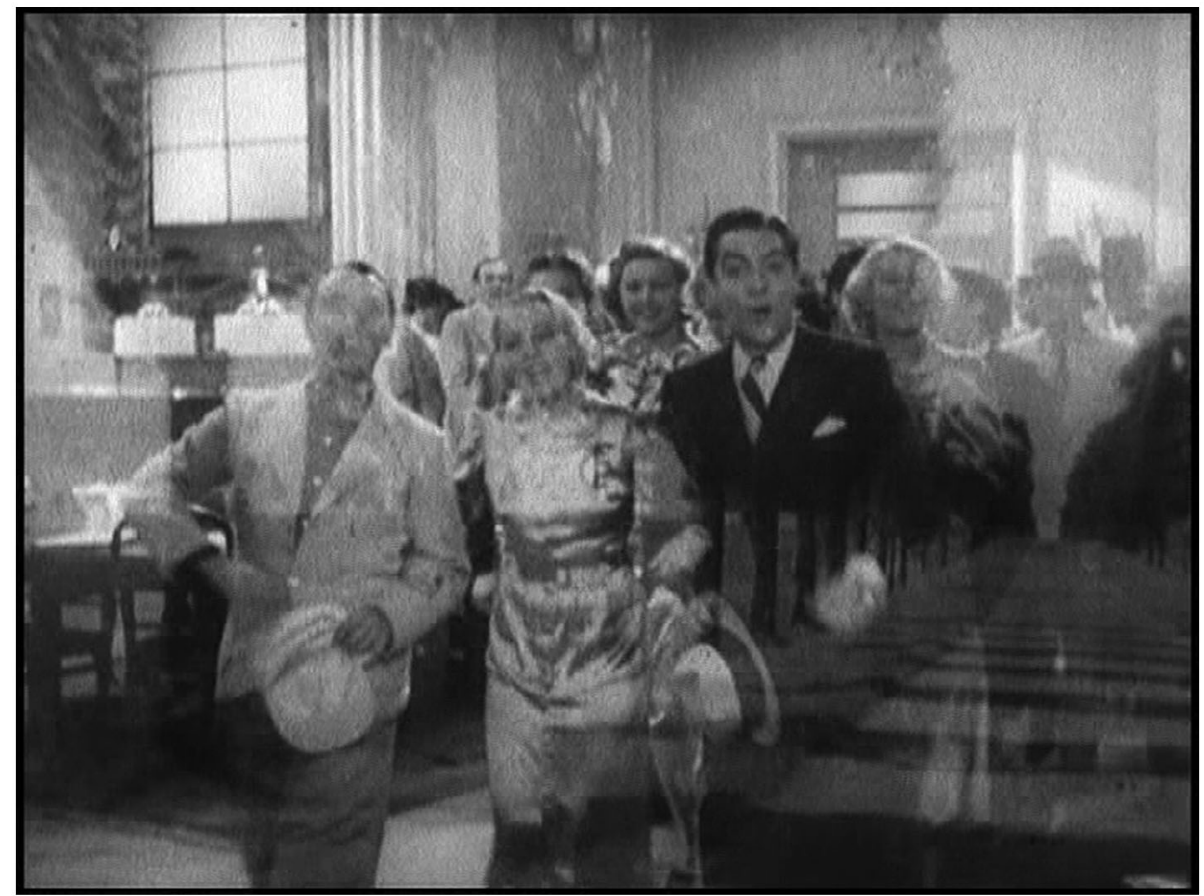

Figure 4. The audience in Prends la route (courtesy René Chateau Vidéo). 
the song by quoting his father who wants him to settle down and work, but he sings:

À mon âge on se fout du lendemain

À mon âge l'argent ne vous tient pas aux mains

On fréquente les bars, on se couche très tard

On se moque du tiers comme du quart

À mon âge aux conseils on reste sourd

À mon âge on ne pense qu'à l'amour

On va de l'une à l'autre, et l'on ne fait rien à demi

À mon âge c'est bien permis ${ }^{43}$

Later in the song, various photographs of (we presume) Jacques's girlfriends come to life and repeat some of these lyrics, adding new ones, followed by Jacques's stern father, and finally a bust of Napoleon materialises as a shadow with an admonishing finger:

(Girlfriend 1) À son âge on se fout du lendemain

(Girlfriend 2) À son âge l'argent ne vous tient pas aux mains

(Girlfriend 3) On fréquente les bars, on se couche très tard

(Girlfriend 4) On se moque du tiers comme du quart

(Father)

À son âge travailler c'est le principal

(Napoleon)

À son âge j'étais déjà général ${ }^{44}$

The fact that it is Napoleon who figures as an admonishing father-figure is significant. These films are about change, about the rejection of what Napoleon might stand for, a well-established and patriarchal State, and the desire for movement required for change. The films depend closely on two types of mobility: the mobility of desire, and the mobility that leads to new communities. I would like to suggest that these mobilities are intertwined in the desire for community as well as communities of desire. And the desire in question is the desire for political and social change, cast in erotic and utopian mode.

There is a tendency to see films by 'auteurs' such as Jean Renoir as the clearest manifestation of the radical spirit of the Front populaire. The little-known and delightful operettas of Pills and Tabet suggest that this radical spirit extends into more popular film forms. Their films are not overtly about the Popular Front. There are no obvious political discourses; unlike Renoir's Le Crime de Monsieur Lange/The Crime of Monsieur Lange (1936), or Julien Duvivier's La Belle Équipe/ They Were Five (1936), the workers do not organise themselves into a cooperative. But they nonetheless manifest what was in the air in the mid-1930s: a newfound freedom, possible after real if ephemeral political change. Musically they built on the jazz forms that had been circulating in France since the mid-1920s, and that were associated with the city, the younger generation and the New World. Indeed, what struck audiences at the time was the freshness of a carefree younger generation. That was not to last of course. The Spanish Civil War was imminent, and Second World War and the Occupation not far away. But in the heady days of the Popular Front, utopia seemed more than real. 


\section{Acknowledgements}

I would like to thank the Beijing Film Academy and the Central Academy of Drama (Beijing) for giving me time during my Visiting Professor duties to turn the original conference paper into a finished chapter.

\section{Disclosure statement}

No potential conflict of interest was reported by the author.

\section{Notes}

1. I have used the standard English translations as found on the Internet Movie Database. Where these are not available, I have given a literal translation of the film title in square brackets.

2. Giusy Pisano, 'Les années trente entre chanson et cinéma', 1895, 38 (2002), http://1895.revues.org/357, §5 (accessed April 14, 2014).

3. Ibid., $\S 10$. He is using a discography produced by the Bibliothèque nationale de France: Giusy Basile and Chantal Gavouyère, La Chanson française dans le cinema des années trente: discographie (Paris: Bibliothèque nationale, 1996). Kelley Conway also uses this data to report that of the 1300 films produced in the 1930s, '686 [...] contain an average of two to three songs per film'. See Kelley Conway, Chanteuse in the City: The Realist Singer in French Film (Berkeley: University of California Press, 2004), 7.

4. Conway, Chanteuse.

5. Ibid., 7.

6. For work on Baker's 1930s films, see Conway, Chanteuse, 139-44; Elizabeth Ezra, 'A Colonial Process: Josephine Baker's French Films', in The Colonial Unconscious: Race and Culture in Interwar France, ed. Elizabeth Ezra (Ithaca, NY: Cornell University Press, 2000), 97-128; and Terri Francis, 'Embodied Fictions, Melancholy Migrations: Josephine Baker's Cinematic Celebrity', Modern Fiction Studies 51, no. 4 (2005): $824-45$.

7. See Phil Powrie, 'The French Musical: Swing and Big Bands in the Cinema of the 40s and 50s', Screen 54, no. 2 (2013): 1-23.

8. See Benoît Duteurtre, L'Opérette en France (Paris: Fayard, 2009).

9. For extended work on MLVs, see Ginette Vincendeau, 'Les films en versions multiples: un échec édifiant', in Le Passage du muet au parlant, ed. Christian Belaygue (Toulouse: Cinémathèque de Toulouse/Éditions Milan, 1988), 29-35; Ginette Vincendeau, 'Les films à version multiple au début du parlant', in Histoire du cinema: nouvelles approaches, ed. Jacques Aumont, André Gaudreault, Michel Marie (Paris/Cerisy: Publications de la Sorbonne/Colloque de Cerisy, 1989), 101-17; Martin Barnier, 'Versions multiples et langues en Europe', 1895, 5 (2013), http://map.revues.org/1490 (accessed October 15, 2014).

10. Barnier, 'Versions Multiples', §19 n23.

11. Ibid., $\$ 30$.

12. Ibid., $\$ 29$.

13. E.g. One Hour With You (Ernst Lubitsch and George Cukor, 1932), Love Me Tonight (Rouben Mamoulian, 1932) and The Merry Widow (Ernst Lubitsch, 1934). 
14. E.g. Naughty Marietta (Robert Z. Leonard and W.S. Van Dyke, 1935), RoseMarie (W.S. Van Dyke, 1936), Maytime (Robert Z. Leonard, 1937), The Girl of the Golden West (Robert Z. Leonard, 1938), Sweethearts (W.S. Van Dyke, 1938), New Moon (Robert Z. Leonard, 1940), Bitter Sweet (W.S. Van Dyke, 1940) and I Married an Angel (W.S. Van Dyke, 1942).

15. See Phil Powrie, 'Luis Mariano, ou l'exotisme ordinaire', sp.no. 'Voyez comme on chante! Films musicaux et cinéphilies populaires en France (1945-1958)', Théorème 20 (2014): 19-29.

16. 'Elegance, dynamism and jazz'.

17. Louis-Jean Calvet, Cent ans de chansons françaises (Paris: Archipoche, 2008), unpaginated. There are numerous biographies of Trenet; the most recent is Jean-Philippe Segot, Charles Trenet: à ciel ouvert (Paris: Fayard, 2013).

18. Raymond Berner, 'Pills et Tabet: l'accord parfait', Cinémonde, 424, December 3, 1936, 904.

19. '[Pills] can tell you lots of anecdotes, because even his name is one, Pills meaning pills in English, as everyone knows. So the Americans called [the duo] "Pills and Tablets"'. Jacques Bardel, 'Fantaisiste, acteur de cinéma, Jacques Pills a chanté et joué sous toutes les latitudes', Photo-Journal, April 21, 1949, 40.

20. For details of Piaf and Pills' short marriage, see Édith Piaf, Ma vie (Paris: Union générale d'éditions, 1964), 73-81; translated by Margaret Crosland as My Life (Harmondsworth: Penguin Books, 1990), 48-54.

21. See http://bdd.eurovision-info.net/bdd/monaco.htm (accessed October 15, 2014).

22. This brief biography relies principally on http://www.lehall.com/docs/biogra phies/pills.pdf (accessed October 15, 2014).

23. See Georges Tabet's autobiography, Vivre deux fois (Paris: Robert Laffont, 1979).

24. Data from the online Encyclopédie multimédia de la comédie musicale et théâtrale en France 1918-1944, http://comedie-musicale.jgana.fr/ (accessed October 14, 2014).

25. The film forms part of a significant corpus of French colonial films, which have had considerable scholarly attention, although to my knowledge this film is not mentioned anywhere in this literature. See for example Pierre Sorlin, 'The Fanciful Empire: French Feature Films and the Colonies in the 1930s', French Cultural Studies 2, no. 5 (1991): 135-51; and Colleen Kennedy-Karpat, Rogues, Romance, and Exoticism in French Cinema of the 1930s (Madison, WI: Fairleigh Dickinson University Press, 2013).

26. 'With the most charming ease, their flexible voices follow parallel paths during the song, split apart, come together again, separate and cut across each other in delightfully unforeseen meanderings. If one stops for a moment, you think it is the other one that has the prettiest voice. But if this one stops in his turn, you have to give up trying to decide. [...] The two voices, both free, nonetheless seem welded together by an imperious musical sentiment. When the tempo accelerates or slows down in mellow or ironic inflexions, there is not the slightest change in the overall tone. It is this perfection that gives them a rhythm both precise and supple, and that allows them to twirl their vocal arabesques with such infallible assurance. The freedom, the fantasy, the purity of their style, the fruit of long hours of training, enchant connoisseurs and lay people alike. Each of their songs [...] is a little masterpiece of perfection and humour.' Berner, 'Pills et Tabet', 904-5. 
27. 'Begins with songs: the songs of youth, of holidays, of joie de vivre. It's an optimistic film that will perk you up.' Olga Denain, 'Avis aux spectateurs', Pour Vous, 444, May 20, 1937, 10.

28. 'This musical fantasy has the irresistible freshness and high spirits of youth./It takes place almost exclusively in exteriors, which is a real plus.' Odile Cambier, 'Prends la route', Cinémonde, 434, February 11, 1937, 119.

29. 'When you've breathed the city air for months on end/You feel weak and you about to faint/Your heart feels weak, you have no appetite, you're feverish/And you're afraid so you go to see your doctor/Who prescribes castor oil/He'd do better if he were clever to tell you/[Refrain] Take to the road old chap/Take to the road and don't worry you'll get better/Take whatever road you fancy/Take to the road and go straight ahead/The road is yours/The Paris air has made you go all sallow/The great outdoors will brighten it up/No more drops for your cough/Take to the road, it's a cure-all/Take to the road and get lost'.

30. 'Is a tandem expensive?/Is a motorbike expensive?/Is a small car expensive?/It isn't that expensive, but it doesn't work!'

31. 'Announces France's entry into modern capitalism: the Front's electoral victory indicates that wage earners are now a majority in society.' Philippe Frémeaux, 'Le Front Populaire: Paris 1934-1939' (1996), http://www.fremeaux.com/in dex.php?option $=$ com_virtuemart\&page $=$ shop.livrets\&content_id $=6264 \&$ pro duct_id=120\&category_id=74 (accessed October 15, 2014).

32. 'The real link between the Popular Front and song can be found wherever the time stolen from work, from the boss, in a strike or thanks to paid holidays allowed lovers to dance, dream, love each other during the time of a song'. Ibid. For an introduction to the Popular Front, see Julian Jackson, The Popular Front in France: Defending Democracy 1934-38 (Cambridge: Cambridge University Press, 1998).

33. 'The gigantic Art Deco Touring Club with its hostesses in satin blouses, the Bugattis, the knickerbockers, the unbelievable glasses of the motorcyclists (without helmets!), the class whore played by Colette Darfeuil, a star now completely forgotten, the secondary roles (Alerme, old fool, Milly Mathis, the tattletale from Marseille), and then the sunny French countryside with its poplar-bordered roads and gracious peasant women who have just come out of the hairdressers. Let's add to this the fact that Pills and Tabet are better actors than you might think, that the young starlet is less insipid than most and that a rather good swing orchestra plays excellent music by George Van Parys. In short [...] it is one of the few French musical comedies to withstand the test of time.' Éric Remy, 'Au temps du Front Populaire', http://www.fremeaux.com/index.php?option= ${ }_{\mathrm{com}}$ content\&task $=$ view\&id $=6264 \&$ Itemid $=0$ (accessed May 28, 2016).

34. See chapter 4 ('Evolutionary Aesthetics: The Hollywood Musical as Darwinian Mating Game'), Darwin's Screens: Evolutionary Aesthetics, Time and Sexual Display in the Cinema (Melbourne: Melbourne University Press, 2009), 73-101.

35. 'You have deep eyes./I've got a temperature./It's the climate./Let's go for a walk ... This atmosphere!/Do you like the tam-tam?/I don't know ... I've been a widow for so long./The tam-tam is a sort of negro music ... let me show you./Do you promise to behave yourself? Naughty boy ...'

36. 'Come with me under the ma/I'm coming/But slowly/Ah! Follow me/I'm coming, willingly/under the man/Come without a frown/Let's go and warble/ Under the mangrove trees/Ah! Under the man man/Under the ma ng roves/ 
Under the mangrove trees/Ah! I want you under the ma/I want you under the ng/The pink mangroves/Let us make love under the man/Take me under the ngr/Let us make love under the rove!' (the final three lines sound like 'under the pallets', 'under the lettuces', 'under the sink' in French).

37. Are there many amusements around here?/Not many, the cinema once a month./Do you like the cinema?/American films especially ... Oh! What if we played at American films? Do you know how?/I'll learn!/It's simple, I put my lips on yours./That's a great idea! Let's try ... we'll see what happens!'

38. 'You look fine like that'.

39. The closest the Popular Front got to anything resembling gender reform was the inclusion of three women in the cabinet; French women did not get the vote until 1944, and abortion was not legalised until 1975.

40. 'Possessed with feverish joy.' Rémy Donald, 'Prends la route', Le Film complet, 1960 (5 June 1937), 4.

41. Pierre Billard, L'Âge classique du cinéma français: du cinéma parlant à la Nouvelle Vague (Paris: Flammarion, 1995), 197; 'considered as the best illustration of the gains made by the Popular Front in relation to paid holidays'. Pills and Tabet songs figure in the CD compilation on the Popular Front mentioned above, Le Front Populaire: Paris (1934-1939) (Frémaux et associés, 1996); this won the Grand Prix du disque de l'Académie Charles Cros.

42. See Richard Dyer, 'Entertainment and Utopia', in Only Entertainment, ed. Richard Dyer (London: Routledge, 1992), 19-35. First published in Movie, 24 (1977).

43. 'At my age you don't care about tomorrow/At my age money trickles through your fingers/You go to bars and you stay up late/You don't care about anything/ At my age you don't listen to advice/At my age you only think about love/You go from one girl to another, and do nothing by halves/At my age it's allowed.'

44. 'At his age you don't care about tomorrow/At his age money trickles through your fingers/You go to bars and you stay up late/You don't care about anything/At his age work is the most important thing/At his age I was already a general'.

\section{Filmography}

À nous la liberté, 1931, René Clair, France.

Andalousie, 1951, Robert Vernay, France/Spain.

Au pays du soleil, 1933, Robert Péguy, France.

Au pays du soleil, 1951, Maurice de Canonge, France.

Mandat d'amener, 1953, Pierre-Louis, France.

Aventure à Paris, 1936, Marc Allégret, France.

Belle Équipe, La, 1936, Julien Duvivier, France.

Bitter Sweet, 1940, W.S. Van Dyke, USA.

Boum sur Paris, 1953, Maurice de Canonge, France.

Capitaine Craddock, Le, 1931, Hanns Schwarz and Max de Vaucorbeil, France/Germany.

Chemin du paradis, Le, 1930,William Thiele, France/Germany.

Comte Obligado, Le, 1935, Léon Mathot, France.

Congrès s'amuse, Le, 1931, Jean Boyer and Erik Charell, France/Germany.

Corniaud, Le, 1965, Gérard Oury, France/Italy.

Costaud des PTT, Le, 1931, Jean Bertin and Rudolph Maté, France.

Dédé, 1934, René Guissart, France.

Feux de joie, 1938, Jacques Houssin, France.

Fille et le garçon, La, 1932, Wilhelm Thiele and Roger Le Bon, France/Germany.

Girl of the Golden West, The, 1938, Robert Z. Leonard, USA. 
Grande vadrouille, La, 1966, Gérard Oury, France/UK.

I Married an Angel, 1942, W.S. Van Dyke, USA.

Il est charmant, 1932, Louis Mercanton, France/Sweden.

Incognito, 2009, Éric Lavaine, France.

Crime de Monsieur Lange, Le, 1936, Jean Renoir, France.

Love Me Tonight, 1932, Rouben Mamoulian, USA.

Marions-nous, 1931, Louis Mercanton, France.

Maytime, 1937, Robert Z. Leonard, USA.

Merry Widow, The, 1934, Ernst Lubitsch, France/USA.

Million, Le, 1931, René Clair, France.

Naughty Marietta, 1935, Robert Z. Leonard and W.S. Van Dyke, USA.

New Moon, 1940, Robert Z. Leonard, USA.

On connaît la chanson, 1997, Alain Resnais, France.

One Hour With You, 1932, Ernst Lubitsch and George Cukor, USA.

Opéra de quat' sous, L', 1930, Georg Pabst, Germany/USA/France.

Paris-Béguin, 1931, Augusto Genina, France.

Pas sur la bouche, 1931, Nicolas Rimsky and Nicolas Evreinoff, France.

Pension Jonas, 1942, Pierre Caron, France.

Point de chute, 1970, Robert Hossein, France.

Prends la route, 1937, Jean Boyer and Louis Chavance, France.

Princesse Tam-Tam, 1935, Edmond T. Greville, France.

Princesse, à vos ordres!, 1931, Hanns Schwarz and Max de Vaucorbeil, France/Germany.

Ronny, 1932, Reinhold Schünzel and Roger Le Bon, France/Germany.

Rose-Marie, 1936, W.S. Van Dyke, USA.

Seul dans la nuit, 1945, Christian Stengel, France.

Sours Hortensias, Les, 1935, René Guissart, France.

Son altesse l'amour, 1931, Robert Péguy and Erich Schmidt, France/Germany.

Sous les toits de Paris, 1930, René Clair, France.

Sweethearts, 1938, W.S. Van Dyke, USA.

Toi c'est moi, 1936, René Guissart, France.

Tourbillon de Paris, 1939, Henri Diamant-Berger, France.

Tout va très bien Madame la Marquise, 1936, Henry Wulschleger, France.

Un caprice de la Pompadour, 1931, Joë Hamman and Willi Wolff, France.

Un soir de réveillon, 1933, Karl Anton, France.

Une femme par jour, 1949, Jean Boyer, France.

Une ravissante idiote, 1964, Edouard Molinaro, France.

Veuve joyeuse, La, 1935, Ernst Lubitsch, France/USA.

Zouzou, 1934, Marc Allégret, France.

\section{Notes on contributor}

Phil Powrie is Professor of Cinema Studies at the University of Surrey. His research focuses on French cinema with a particular emphasis on issues of gender, and more recently, the interface between music and the cinema. He has authored or co-authored 10 books, edited or co-edited a further nine, covering both recent French cinema and cinema in the silent period. He has also published over 90 journal articles and book chapters. He established the Association for Studies in French Cinema with Professor Susan Hayward (Exeter) in 2000. Through this association, he is Chief General Editor of the only journal worldwide devoted entirely to French cinema, Studies in French Cinema. In recognition of his work and services to French cinema, he was decorated in 1999 by the French government and made Chevalier dans l'Ordre des Palmes Académiques. 